\title{
The Learning Analysis of the Political Text: Structure and Functions of the Election Address (on the Example of $G$. Zyuganov's Speeches)
}

\author{
Dilyara Basyrovna Garifullina*, Tatiana Konstantinovna Ivanova and Ekaterina \\ Vladimirovna Smyslova
}

\begin{abstract}
Department of Foreign Languages in the field of International Relation, Kazan Federal University, Kazan, Russia
\end{abstract}

\begin{abstract}
Good number of researchers have demonstrated the need for online training for faculty members in various countries around the world in recent years. However, most of these academic researchers have discussed the different effects of the online training system. The study deals with the genre structure and formation of a special type of the political text which is an election address of a political leader to the electorate. The article considers the history of the appearance of the public speech genre in Russian political discourse, its functions and linguistic features that solve the problem of revealing the main ideological content at the lexical level. The paper also focuses on the techniques used in this authorial text. They are examined from the perspective of identifying manipulative strategies and tactics of influencing the emotional, rational, and moral-ethical spheres of the electorate, and their implementation at the language level. The research material was the texts of Gennady Zyuganov's election addresses in 2000 and 2019 taken from the Internet sources, as well as the accompanying comments estimated to be about 50 sources. To increase the degree of objectivity of the results obtained, machine text processing (SEO-type text processing programs, vaal.ru, wordstat.yandex and others) was also used. In the course of the study the linguistic characteristics of the implementations of the political address functions (influence, inspiration, advocacy and propaganda, informing), typical of this type of political statements, are revealed along with the established dynamics of changes in rhetoric by Gennady Zyuganov as the leader of a political party (the Communist Party) and its leading representative.
\end{abstract}

Keywords: Linguistics, Speech influence, Political statement, Political communication, Analysis of political texts.

\section{INTRODUCTION}

Nowadays it is impossible to imagine solutions to global problems facing both an individual country and humanity as a whole without their broad public discussion. Making a political decision is a matter of how convincingly and evidently the consequences of such a decision are presented, how valuable they are to the public, and how many supporters it will gain in the course of discussion. All information that aims to bring to the layman the current state of political affairs in a country or the world can be defined as a political text.

According to N. S. Valgina, the main features of the text are the categories of coherence-integrity (the content aspect of the text) and cohesion connectedness (the expressive aspect of the text), the analysis of which is related to the question, due to which mechanisms the individual elements of the language form a unity that semantically exceeds the sum of the contents of the included units (Valgina 2003). Comprehension of the text as the main unit of communication is also conditioned by the fact that there has been a recent significant increase in interest

*Address correspondence to this author at the Department of Foreign Languages in the field of International Relation, Kazan Federal University, Kazan, Russia; Tel: +7(927)4452954; E-mail: a.researcher40@yahoo.com in the problems of language personality, speech influence (Abbasi 2015), speech consciousness, which is an "internal process of planning and regulating external activities using language signs" (Tarasov 2019).

A. G. Altunyan defines the political text as a text that deals with current political issues and is addressed to a mass audience. At the same time, he notes that the text becomes political if it is considered as such by the main subject of the political process: it is the political audience in a democratic country and the government itself or its institutions in an authoritarian country (Altunyan 2006). From the communicative point of view, the political text has the author, the text itself, and the addressee, the one to whom the text is directed. Another very important component of the political text is its attractiveness. And it is certainly impossible not to take into account the ideological function of the political text. Any politician transmits their own, favourable picture of the world to the audience. To implement all the components of the political text, the authors resort to various rhetorical and stylistic methods of constructing arguments, which we consider in this article as exemplified by election addresses.

The paper focuses on the election address as a specific genre related to a political and ideological 
document. Further, its linguistic parameters will be considered depending on the functions performed by them in order to establish its specificity (Tushev, Bushkanets 2019; llikova 2019).

\section{METHODS}

Linguistic research on the problems of speech influence of ritual texts is mainly descriptive. Although it is obvious that it is the results of linguistic analysis being basic for all other types of text analysis. The analysis of speech influence is also carried out in psychology, where it differs from the linguistic approach primarily by the use of psychological methods ( $\mathrm{J}$. Austin, J. Searle), as well as the method of constructing subjective semantic spaces using factor analysis (Ch. Osgood, J. Kelly, V. F. Petrenko, O. V. Mitina, etc.). The research is based on works on the specifics of political language (Bayley 2019, Garcia Santos 2017, Morik 2002, Belyanin 2018, 2009), critical discourse analysis (Van Dijk 2013, Wodak 2019).

Statistics processing of theoretical and experimental data was carried out by means of the electronics software vaal.ru, wordstat.

To identify manipulative and argumentative strategies and tactics of influence on the emotional, rational and moral-ethical spheres of the electorate, the verbatim transcripts of Zyuganov's election addresses were analyzed in terms of techniques and linguistic material used in the speeches of the above-mentioned politician. G. Zyuganov is a Russian statesman who has been the Chairman of the Central Committee of the Communist Party of the Russian Federation (Kommunisticheskaya Partiya Rossiyskoy Federatsii, KPRF), head of the Communist Party fraction in the State Duma of the Federal Assembly of the Russian Federation since 1995. As the leader of the political party, Zyuganov has stood for election to the post of the head of the Russian state four times, and in terms of the number of votes received each time he came second after the President who was later elected.

\section{RESULTS AND DISCUSSION}

According to SEO statistics [https://istio.com/rus/ text/analyz/], Zyuganov's address to the nation in 2000 consists of 2405 words. The following data provide individual language elements repeated in the election speech expressed as a percentage of the total text volume.
The linguostylistic analysis of Zyuganov's election addresses carried out with the help of electronic data processing revealed the most frequent stylistic techniques of phonetic, lexical, syntactic and lexicalsyntactic levels.

From the linguistic perspective, Zyuganov's election speech has a traditional composition, which consists of an introduction, the main part including thematic blocks, and the conclusion. From the point of view of speech influence, the linguistic embodiment of the ideological content reflected in the compatibility and frequency of individual language elements use is of great interest.

The address begins with establishing contact with listeners: "Grazhdane Rossii! Moi sootechestvenniki». The use of the pronouns 'moi', 'my' is a frequent speech tactic of political discourse as it reduces the distance between the speaker and the audience. It should be noted that Zyuganov's usage of the pronoun 'my' has an inclusive character, i.e. 'ya + vy'. In this case, the individual 'ya' gives way to community, where the 'ya' is a part of civil society, a citizen of Russia. This technique is a means of establishing close contact with the audience. The sentence "Ya sam po professii $\mathrm{i}$ iz sem'i potomstvennyh uchitelej i znayu, kakogo ogromnogo napryazheniya stoit eta ezhednevnaya, chasto neblagodarnaya rabota $\mathrm{s}$ podrastayushchim pokoleniem» emphasizes his belonging to the common people, understanding the problem from within. The general political trend towards rejection of revolutionary changes manifested most clearly after the mass protests of 2011-2012. It can be stated that for the right-wing and centrist parties the revolution is an undesirable event and 'uncomfortable past'.

Gennady Zyuganov also uses the pronoun 'ya' in the sense of 'individual personality, individual citizen'. This device indicates the intention to draw attention towards himself, to appear before the voters in the role of the leader of the situation: "Ya nemedlenno izdam ukaz ob ekstrennyh merah po bor'be s prestupnost'yu, obespechenii bezopasnosti grazhdan, soblyudenii zakonnosti i pravoporyadk a», "Ya budu ih vsyacheski razvivat' i ochishchat' ot iskazhenij el'cinskoj epohi». This is the way one of the communicative tasks of positive self-representation is realized.

Being typical of the election address, discrediting of the opponent is carried out by the following lexical and stylistic means: 
- metaphors: 'paralich otechestvennoj nauki', 'utechka umov', 'caryashchaya nishcheta', 'opustoshenie vashih dush', 'rabochie i krest'yane stanovoj hrebet nacii', etc. (11 - 0.4\%);

- epithets: 'zheleznaya ruka', 'grabitel'skaya privatizaciya', 'pozornaya zadolzhennost' (10-0.4\%);

- words with negative connotations: epidemiya, genocid, bezrabotnye, bezdomnye, bezhency, korrumpirovannyj chinovnik, killery, mafioznye del'cy (40-1.5\%);

- gradation: My lishilis' poloviny promyshlennosti. Nashe sel'skoe hozyajstvo prishlo v upadok. Stranu rastaskivaet po kuskam gorstka oligarhov i korrumpirovannyh chinovnikov, ustanovivshih v strane svoyu kriminal'nuyu diktaturu. Kolossal'nye, ischislyaemye sotnyami milliardov dollarov bogatstva ukradeny u naroda i vyvezeny za rubezh. (10 - 0.4\%);

- opposition: Rossiya stoit sejchas pered vyborom s kem ej idti $v$ XXI vek. S naslednikami El'cina? $S$ ih posobnikami iz chisla byvshej nomenklatury? $S$ ne imeyushchimi kornej $v$ Rossii oligarhami i ih prisluzhnikami? lli zhe s temi, kto pokonchit raz i navsegda $s$ pozornym naslediem el'cinizma i povedet Rossiyu k nacional'nomu vozrozhdeniyu i velichiyu? (3 - 0.1\%)

Most of the expressions listed above (about 2.6\% of the total vocabulary) have a negative connotation, as they express disapproval and criticism of the existing policy of the opponents. However, it is quite natural for this genre when the presidential candidate, describing his course, makes maximum use of lexical units with a positive connotation: ozdorovlenie rossijskoj ekonomiki, veroj i pravdoj sluzhit' Rodine, svobodnaya vlast', deesposobnyj i aktivnyj parlament $(0.4 \%$ of the total vocabulary). Advocacy and propaganda function is realized through the imperative mood: $\mathrm{Ne}$ ver'te! Podumajte horoshen'ko. Dover'te nam upravlenie stranoj!; and the rhetorical question: Vopros byt' Rossii il' ne byt'?

Being an essential content component of the election address, freedom of choice is implemented by Zyuganov's insistent call to go to the polls: I kazhdyj grazhdanin dolzhen dat' na nego otvet $v$ hode predstoyashchih vyborov prezidenta Rossijskoj Federacii. Sud'ba Rossii, vasha sud'ba, sud'ba vashih detej i blizkih sejchas $v$ vashih rukah. Vash golos mozhet spasti Rossiyu.
At the lexical and semantic level, the text of the election speech clearly shows the image of Russia as a country facing a decisive choice of the future fate of both the state and the people.

The word 'Rossiya' is used 37 times in the text, which is $1.5 \%$ of the total volume. It is significant that the image of 'Rossiya' in the text is personified and it acts as the personification of the state and the country as a whole, for example, Rossiya stoit pered vyborom, Rossiya lishitsya budushchego, etc. This technique helps to identify the moral and ethical beliefs of the author, who associates the country with the citizens who are faced with a choice of further path.

The lexeme 'narod' (23 - 0.9\%) is used in various phrases that have both a negative connotation (genocid narodov, antinarodnye reformy, vymiranie naroda) and a positive connotation: velikij narod, narodovlastie, sluzhit' narodu, etc.

The lexical unit 'strana' $(21-0.8 \%)$ is synonymous with the word Rossiya: «Dover'te nam upravlenie stranoj!», «Imenno pri Sovetskoj vlasti nasha strana dostigla zenita svoego velichiya», etc.

Combining the semantics of the concepts 'strana', 'Rossiya' and 'gosudarstvo' (15 - 0.6\%) increases the emotionality of the statement, appealing to the unity of the government and the electorate. The lexical unit 'gosudarstvo' is used in several meanings: 1) 'government, power', which provides comfortable conditions and social guarantees for its citizens: "Gosudarstvo smozhet okazat' maksimal'noe sodejstvie vsem nuzhdayushchimsya v uluchshenii zhilishchnyh uslovij»; 2) 'country': «Budushchuyu Rossiyu v soyuze s bratskoj Belorussiej my vidim svobodnym mnogonacional'nym gosudarstvom s mnogoukladnoj ekonomikoj». Thus, the entire election speech is centered around the key concept of Rossiya, which is revealed and supported by the contextual synonyms 'strana' and 'gosudarstvo'.

Thus, it can be argued that a certain selection of words and speech techniques helps a politician to appear before the audience as a sincere, caring person about their people. The facts and problems that concern the audience are expressed consistently, which indicates the professionalism of the politician. The audience may form the opinion that the policy of this particular candidate is correct and safe. Given the fact that a large percentage of the voters in our country are focused on the individual first and not the election programme, all of the above is of great importance. 
The speech of the presidential candidate is generally straightforward, he openly criticizes Yeltsin's policies, repeatedly saying epoha El'cina, nasledniki El'cina. In terms of phonosemantics the experimental assessment of the text of the election statement made on the basis of the VAAL project [http://www.vaal.ru/] describes the text as: "frightful, simple, evil, majestic, rude, cold, powerful, brave, loud". Based on this, it can be claimed that this address is straightforward, harsh and sometimes aggressive.

The main themes derived from the concepts mentioned in the election address are issues of unemployment, poverty, economic crisis, and deadlocked state policy. These topics coincide with the conceptual content of the speeches of other candidates of that period, such as V. V. Putin, V. V. Zhirinovsky, G. A. Yavlinsky, S. S. Govorukhin and others.

These topics remain relevant in Zyuganov's election address, made 19 years later. Statistics processing of the 2019 text using VAAL system almost duplicates the results of earlier speeches by Zyuganov: the adjectives 'powerful', 'brave', 'rude', 'loud', 'simple' define the text. These facts show that the phonosemantic characteristics of the politician's speech are preserved. However, it should be noted that in 2019 Zyuganov addresses the nation on behalf of the party indirectly, as P. Grudinin (a businessman and politician) becomes the candidate from the Communist Party for the post of President in that period.

Zyuganov's address to the nation in 2019 consists of 762 words [https://istio.com/rus/text/analyz/]. The dominant lexemes are the following words:

'KPRF' (7-0.9\%) - the party designation, formed by abbreviation, stands for 'the Communist party of the Russian Federation', therefore it is used in the address in its literal meaning ' $u$ KPRF i eyo soyuznikov', 'predstavitelej KPRF', 'programma KPRF', and so on; the abbreviation is familiar and neutral for the Russianspeaking community; at the same time, the use of this abbreviation in the text is an indication of the author's ideological platform and a key to understanding the critical remarks made by this leader in relation to other political movements and parties;

It should be noted that in comparison with the speech of 2000, the address "friends" and "dear friends" appears in this speech, which indicates a desire for closer social contacts with the audience and a reduction in the distance of communication. Then the speaker describes the political situation in the country, according to the laws of political rhetoric: the political dichotomy "native - alien", in which one of the parties discredits the other on the basis of available data and subjective modality.

Discrediting the current policy is achieved by the following language devices:

Use of political metaphors ( $0.3 \%)$ : prevalence of the vocabulary with a negative connotation in the text $(0.9 \%)$ : use of gradation to increase the impact $(0.1 \%)$ : The inclusive nature of the pronoun 'my' in the 2019 address means. The next part of the address defines the audience which the politician pins his hopes on. In this part of the speech the author resorts again to the associative model 'my - chleny partii KPRF, partiya KPRF', which was not in the first performance of 2000 , where 'my' was represented through the inclusion in the civil community in Russia. This is the way the party and corporate nature of the expressed position is emphasized, when Zyuganov does not formally run for election, but expresses his political party affiliation.

The positive image of the party is realized by appealing to the historical past: «Lenin i Stalin sozdali pervoe $\mathrm{v}$ mire gosudarstvo trudyashchihsya. $\mathrm{V}$ nevidannye sroki ono sovershilo proryv $v$ budushchee, provelo industrializaciyu i likvidirovalo negramotnost', vyvelo cheloveka v kosmos i sozdalo ekonomicheskij bazis, plodami kotorogo my pol'zuemsya do sih por. Dokazatel'stvom sily i pravdy "sovetskogo proekta» stala nasha Velikaya Pobeda nad fashizmom».

In conclusion, Zyuganov gives the freedom of choice to the voter: "Vperedi - nashe vremya! Vybor za vami! Vmeste - my sila! Vmeste - pobedim! » This proclamation at the end of the address is structurally correlated with the first text, but it also emphasizes the importance of choosing the specific party in contrast to the concept of greatness of Russia used earlier.

Thus, the 2019 speech is less emphatic from the lexical point of view, and lexical units are less expressive from the emotional point of view. Presumably, these facts are explained by the fact that in 2019 Zyuganov addresses on behalf of the head of the election staff, and not the presidential candidate. This is a speech in support of the like-minded candidate and his task is to instill confidence in the continuation of the party policy and the continuity of the ideas expressed by the party members. 


\section{SUMMARY}

The comparison of two addresses from different eras of the country's historical development and personal career allows us to observe changes in both the choice of language devices and the intentions of the individual politician. Gennady Zyuganov's 2000 election address is characterized by enthusiasm and confidence in the possibility of changing the state's policy, and the 2019 address implicitly expresses support for a new generation of representatives of the Communist Party.

The conducted analysis shows that the analyzed speech genre is a complete message that has coherence, a certain content and purpose, performing the communicative function of influence and attracting attention. Typical tasks of the election speech (i.e. to draw attention, describe a problem, present the solution clearly, and influence the electoral behavior of the audience) were carried out. The individual devices used by the author of the election address are subject to the general logic of the statement and the structural organization of the text. However, backed by the linguistic and phonosemantic analysis, the possibility of improving the quality of impact by making changes to the overall emotional and expressive background of the text can be considered.

\section{CONCLUSIONS}

The genre of the election address, despite a number of permanent structural and semantic elements, is a living and dynamic structure that changes over time following the socio-political transformations of public life.

The election address has a ritual character. This is determined by its cyclical nature and also by the fact that this appeal is characterized by scenario, role structure and symbolism. The main participants are presidential candidates and voters. The goal of each candidate is to provide the most 'reliable' information about themselves, create a trusting attitude of voters, cause them to have positive emotions towards themselves and negative emotions in relation to the opponent.

Election speeches usually reflect current socioeconomic problems of society that are of the greatest interest to certain groups of voters. There are mainly two basic communication strategies implemented according to Aristotle. They are manipulative and argumentative, which correlate with the emotional (pathos) and rational (logos) aspects of rhetorical influence. The functions of election appeals are influence, inspiration, advocacy and propaganda, informing.

The influence function is aimed at exerting emotional pressure on voters and appealing to their feelings and reason. The inspiration function is to inspire the nation for great things to come and glorify traditional values, as well as to appeal to the past as the source of traditional values of the nation and the future, which should inspire voters with hope, faith in success and confirm the continuity of established national traditions. The advocacy and propaganda function promotes the dissemination and introduction of the ideas and ideology of a party a candidate represents into the minds of potential voters. The information function is aimed at informing the electorate about political actions, intentions, course and position of the candidate themselves.

\section{ACKNOWLEDGEMENTS}

The work is performed according to the Russian Government Program of Competitive Growth of Kazan Federal University

\section{REFERENCES}

Abbasi, M. S., Tarhini, A., Elyas, T., \&amp; Shah, F. (2015). Impact of individualism and collectivism over the individual's technology acceptance behaviour: A multi-group analysis between Pakistan and Turkey. Journal of Enterprise Information Management, 28(6), 747-768. https://doi.org/10.1108/JEIM-12-2014-0124

Altunyan A.G. (2006) Analiz politicheskih tekstov: uch. posobie / A.G Altunyan. - M.: Universitetskaya kniga; Logos, 206. $384 \mathrm{~s}$.

Bayley P. (2019). Live oratory in the television age: The language of formal speeches // G. Ragazzini, D.R.B.P. Miller eds. Campaign language: Language, image, myth in the U.S. presidential elections 1984. - Bologna: Cooperativa Libraria Universitaria Editrice Bologna, 1985. P. 77-174.

Belyanin V. P. (2009). Introduction to psychiatric literature / V. P Belyanin - Verlag Otto Sagner. Specimina Philologiae Slavicae. Band 107. - Munchen, 1996. - 298 p.

Belyanin V. P. (2018) Psycholinguistics. Textbook. / V. P. Belyanin Moscow: Flinta: Moscow Psychological and Social Institute, 2009. - 416 p. (Student library/ Russian Academy of Sciences education, Mosc. Psych. and Soc. Inst.). - ISBN 589349-371-0 (Flinta) - ISBN 5-89502-421-1 (MPSI).

Garcia Santos J.F. (2017). El lenguaje politico: En la Secunda Republica y en la Democracia // M. Alvar ed. El lenguaje politico. - Madrid: Fundacion Friedrich Ebert, Instituto de Cooperacion Iberoamericana, 1987. P. 89-122.

Glazunova, S. (2020). Digital media as a tool for non-systemic opposition in Russia: A case study of Alexey Navalny's populist communications on YouTube (Doctoral dissertation, Queensland University of Technology).

Ilikova L. (2019) The five star movement: From a blog to Italian government II Sovremennaya Evropa, Issue 4, Pages 129140.

https://doi.org/10.15211/soveurope42019129139 
Morik K. (2002). Uberzeugungssysteme der Kunstlichen Intelligenz: Validierung vor dem Hintergrund linguistischer Theorien uber implizite Ausserungen. Tubingen: Niemeyer, 1982. 269 p.

Tarasov E. F. (2019). Speech impact: methodology and theory [Text] / E. F. Tarasov // Optimization of speech influence [ed. by R. G. Kotov]. - Moscow: Nauka, 219, P. 5-18.

Tushev A, Bushkanets L, Letyaev V. (2019) Complex analysis of political speech // Journal of Sociology and Social Anthropology. Vol.10. Is.4. P.170-174. https://doi.org/10.31901/24566764.2019/10.04.307
Valgina N. S. (2003). Theory of the text: textbook / Valgina N. S. Publishing house: Logos, 2003. $-280 \mathrm{p}$.

Van Dijk Ten A. (2013). Diskurs i vlast': Reprezentaciya dominirovaniya $v$ yazyke i kommunikacii / Ten A. van Dijk. M.: Knizhnyj dom «LIBROKOM», 213. - 344 s. (in Russian)

Wodak R. (2019). Language. Discourse. Politics / Translated from English and German. - Volgograd: "Change", 97, 139 p.

Received on 23-11-2020

Accepted on 31-12-2020

Published on 18-01-2021

DOI: https://doi.org/10.6000/1929-4409.2021.10.17

(C) 2021 Garifullina et al.; Licensee Lifescience Global.

This is an open access article licensed under the terms of the Creative Commons Attribution Non-Commercial License (http://creativecommons.org/licenses/by-nc/3.0/) which permits unrestricted, non-commercial use, distribution and reproduction in any medium, provided the work is properly cited. 